\title{
Public urbanistic Policies to Favor ACCESSING TO SOCIAL HOUSING
}

\begin{abstract}
Purpose: This paper aims to analyze the importance of the urbanism planning and its relation with the effectiveness of the recently approved Spanish Housing Plan 2018-2021 of measures to favour access to dignified housing as a welfare state policy.

Methods: With this purpose, the paper shows that the origin of the access to social housing depends on the urbanism activity using the method of the study of the enacted law.

Results: The result of this research underlines that legislator must take in account this relation when approving urbanism regulations.

Discussion: The central discussion is focused on improving urbanism regulations in order to ease the real access to dignified housing as a goal to lead to more effectiveness in the Housing Planning application.
\end{abstract}

KEYWORDS: social housing, public policies, welfare state, planning, urbanism.

\section{INTRODUCTION}

Access to dignified housing is a social right included in the Spanish Constitution as a value that should inspire public policies to build a society in which the welfare state is as widespread as possible. Housing is, as well, one of the three pillars of the cities' economic development joint with money and transport (Janer y Durán, 1946, p. 926). With the purpose of complying with this constitutional mandate, the Spanish State periodically approves 
housing plans that include measures to facilitate access to decent housing for people who gather the requirements established by public policies to bring assistance or aid to purchase housing, but which entail some limitations to the transmission of the domain and to the lease of such houses in order to ensure that they are enjoyed for the same sector of the population to which they were initially addressed, and to prevent lucrative business from being done in relation with them. Notwithstanding these social policies are linked with the previous policies about the use of the ground, so one of the limitations that conditioned the future of the access to social houses depends of the urbanism policies formerly applied to create urban ground that could be addressed and reserved to social housing.

\section{THE RIGHT TO ACCESS HOUSING IN ITS LEGAL CONFIgURATION IN SPAIN}

According to the article 47 of the Spanish Constitution: "All Spaniards have the right to enjoy decent and adequate housing. The public authorities will promote the necessary conditions and establish the pertinent laws to enforce this right, regulating the use of the land in accordance with the general interest to prevent speculation. The community will participate in the capital gains generated by the urban action of public entities". The article 47 in fine refers to the need to connect the urban activity with its repercussion for the benefit of society, because it was after the Spanish Constitution of 1978 that it had become a social right, but we found a disconnection between urbanism and housing regulation (Jardí Casany, 1952, p.78). It has been highlighted that the equal-distribution mechanisms of our urban legal system do not allow to transfer de benefit between different sorts of soil classes, for which certain limitations are observed (Agudo González, 2009, p.150).

Housing legal nature requires some clarifications to understand its scope and content. The first one is that it is located within Chapter III of Title I of the Spanish Constitution, regulating the Guiding Principles of Social and Economic Policy, so it is not a Fundamental Right, and its protection cannot be considered as one of this kind. Secondly, we must consider that the manifestation of the configuration of Spain as a social and democratic State of Law, means in relation to the right to dignified housing, that it is not 
a subjective right that would confer to its holders an action for obtaining directly a dignified and adequate housing, in this sense it is configured as a value to be promoted by the public powers (as a guideline, thus the Constitutional Spanish Court Decision No. 155/1988, of July 20, in its Legal Foundation number 2). However, we can mention that in other European countries is possible to find examples of a materialization of this right in a subjective right, as in the Superior Court of Contentious-Administrative Court of Nordrhein-Westfalen (Germany), of March 4th, 1992 that establishes the limits in which a local administration is obliged to grant housing to persons without housing, in a case of exceptional recognition, through prudential means (González-Varas Ibáñez, 1992, page 843). Undoubtedly, this possibility goes much further than simply contemplating the right of access to decent housing, as an inspiring principle. Despite its objective delimitation, from the subjective point of view, this right is much broader since Article 13.1 of the Spanish Constitution and the Organic Law 4/2000 of January 11, extend the right to access a decent housing to the foreigners with legal residence in Spain. Thirdly, must be emphasized that Article 47 of the Spanish Constitution focuses on the regulation of the land, that is, on urbanistic matters, so that the right to access decent housing cannot be understood separately and independently to urban planning.

\section{SOCIAL HOUSING PROTECTED THROUGH URBANISTIC LAW}

Incidence of urbanistic regulation on access to decent housing can be seen from a historical perspective, since the Urbanistic Law of 1992 had 310 articles and the Land Law of 1998, only 44 articles, which meant the liberalization of the soil (De la Vallina Velarde, 2000, p. 337 and Iglesias González, 2005, p. 518), since the no-developable land in this Urbanistic Law is not a residual type of land delimited from the setting of the limits of the developable land, and because unless there were worthy values of protection that would force to configure as no-developable land the soil (Munar Fullana, 2000, p. 786), the land that does not have these values, could be catalogued as a developable one (Quintana López T., 1999), p. 269). The later urbanistic regulations are more social than the 1998 Urbanistic Law and introduce other mechanisms 
to protect social housing. Thus, the Royal Legislative Decree 2/2008, of June 20 , which approves the revised text of the land law, is very protective of the environment, but the only mention of the protection of the right of access to housing we find in it is a provision that regulates the reservation of land to be addressed to social housing. Subsequently, the Royal Legislative Decree $7 / 2015$, of October 30 contains many more references to the promotion of social housing. The importance of urban law is not limited, from the point of view, of social rights to access to decent housing, but can go much further because it serves as an instrument of integration and social cohesion, issues somewhat linked to access to decent housing and even other rights, even of a fundamental nature (Ponce Solé, 2003, p. 71). Currently, it can go much further because it must be available to public authorities as an instrument to achieve the implementation of the Sustainable Development Goals promoted by the United Nations (Barrio Andrés, 2016, p. 5). This instrumental character for the attainment of general or public interests can be subject to judicial control through techniques that allow controlling the adequacy to the legality of the urban public function (Cabello Martínez, 2011, p. 256), since the Administration can only exercise his powers to achieve the public interest, under penalty of deviation from power.

In urban planning regulations there are two issues that must be analyzed more deeply: the first one is the change of the law of the urban property right in the different rules regulating the land; the second is the analysis of the progressive implementation of mechanisms tending to favour the generation and maintenance of the protected land that is destined to improve social housing.

Regarding the change of the land law of 1998, this law has the character of an economic policy instrument, since it fostered the development and growth of privately owned assets, both because it gave rise to the revaluation of land for its owner, as it caused the boom in the economic activity of building. This Law received some criticism, because it was considered by some authors as an involution (García-Bellido García de Diego, 1998, p. 19). This Law contains a single reference to "housing" in its article 40 , where the social character of the right is built only on the right of "reversion of the expropriated land for urbanistic reasons. This law also contains a change in 
the conception of the content of the right of the land. A difference regarding to what was foreseen in the 1992 legislation, in which the ownership of the land was conceived with an evolutionary character, so that the landowner acquired the faculties that integrated his domain to the extent that he fulfilled his urbanistic obligations, the Law 6/1998 established an urban planning regime for land ownership of a statutory nature, so that the owner always has the rights and obligations that integrates the status of land ownership, but that is different according to the urban soil, developable or no-developable (rustic) one, although it depends on its classification, as in the previous system did (Ramón Parada, 1998-1999, p. 144).

Looking at the current implementation of mechanisms tending to the generation and maintenance of urbanistic protected land that will be destined to social housing, we appreciate that there are more measures nowadays than ten years ago.

So, in the Land Law of 2008, measures were introduced to promote access to social housing. In this sense, Article 4 includes the rights of citizens to access housing, as well as to promote the activity of opening urban planning through the private initiative in article 6 . A guarantee that the soil would be used to build social houses was implemented in relation with the social function of the property, such as the application of responsibility for noncompliance with the approval or execution of planning - articles 11.5, 25 and 26. A specific title, Title V, was introduced in the Land Law of 2008 to regulate its social function. This social function of the property is guaranteed by the legal provision of a cataloque of measures that allows compliance with the law even if the owner fails in fulfilling the obligations that the urbanistic law imposes. They are the following: subsidiary execution, forced substitution, compulsory sale regime, and expropriation for breaching of the social function of the property. The reserve of land was also regulated for building houses with a regime of public protection with a fixed maximum price for sale, rent or other contractual way to access to housing.

Finally, the Royal Legislative Decree 7/2015, of October 30, declares that public administrations must allocate adequate and sufficient land for productive uses and for residential use, with a reservation in both cases, of a part of the lands to public protected buildings that could be addressed to 
social housing. This reserve will include, as a minimum, the land needed to make 30 percent of the residential building area planned by the urban planning in the rural land that will be included in new urbanization actions and 10 percent in the urbanized land that must undergo renovation and rehabilitation. The reserved land may be set or exceptionally allow a lower reserve or exempt them for certain public actions, provided that, in the case of new urbanization actions, it was guaranteed the full compliance of the reserve within its territorial scope.

In addition, Royal Legislative Decree 7/2015 also recognizes the right to decent housing when regulating the application of the land reserve for protected housing. This right must be interpreted in accordance with its article 1 that states that this law guarantees the effectiveness of the right to enjoy decent and adequate housing. Consequently, Article 3.4.2 states that the land linked to a residential use by urbanistic planning is at the service of the effectiveness of the right to enjoy decent and adequate housing, in the terms provided by the legislation on the subject and article 5.a) establishes that all citizens have the right to enjoy decent, adequate and accessible housing.

The former principles that declare this rule are materialized in the regulation of the reservation of land to guarantee the dignified housing and the rights of return and rehousing that the law recognizes to the owner or the tenant in the urbanistic public activity.

The reservation of land to guarantee decent housing is regulated currently within the basic statute of the promotion of urban actions, in article 18, as those linked to the promotion of urban transformation actions and building actions. Among others, the urbanization actions include the legal requirements as to deliver to the Administration the minimum of ground reserved for the streets, free spaces, green areas and the rest included in the urbanistic planned action. In these land reserves are included the management instruments referred to the termination of public housing, some of them bond with a protection regime, and others limited because of their exclusive destination is be used for renting as a place to live.

The rights of return and accommodation are regulated in article 19.1, 19.4 and 19.5 of Royal Legislative Decree 7/2015, and through them in the execution of actions in the urban surrounding that require the eviction of 
legal occupants from their habitual residence must be guaranteed the right of those to be rehoused. To make effective the right of rehousing, it will be necessary to offer a new dwelling for each of the dwellings affected by the action, either in the same scope of action, or, if this is not possible, in an action that would be executed as soon as possible. When there are no possible rehousing, holders of the right are entitled to its economic equivalent.

\section{THE PROMOTION OF THE RIGHT TO ACCESS TO A LIVING PLACE THROUGH HOUSING PLANS}

The Spanish Royal Decree 106/2018, of March 9, which regulates the housing plan 2018-2021 materializes the second phase of public action to facilitate access to social housing. Through this regulation it can be offered access to housing after having been generated in the first phase, the urbanistic one. But there are great disparities between the regulation of the access to social housing and the urbanistic regulations (Vaquer Caballería, 2017, p. 69), existing a traditional disagreement in both areas (Alli Aranguren, 2005 , p. 59). For this reason, the urban matter should be regulated later in its subsequent impact on social housing, since it tends to cover only the needs of housing in proportion to the availability of collective resources (Gardini, 2018, p.89).

Main objectives of the State Plan of Housing 2018-2021 are the promotion of rent and the promotion of rehabilitation and regeneration of urban and rural buildings, facilitating young people's access to the enjoyment of decent and adequate housing in the rental regime, and facilitating the same but referred to elderly people, or those who are disabled persons through the promotion of the rental housing park, that does not excludes the new promotion buildings within a margin that depends on the growth of the number of inhabitants in each locality.

With the promotion of renting is intended to reduce the negative consequences of the Spanish housing system's trend based in the use of a scheme of home ownership as a characteristic of the Spanish park facing the one that is used in other European countries where renting is much more usual (Bassols Coma, 2003, p.106), and the number of vacant dwellings is also reduced (Fernández Méndez and Justo Rodríguez, 2017, p. 54). 
The Housing State Planning is intended to favour access to social housing in order to face the degradation of the constitutional concept of decent and adequate housing (Sánchez Blanco, 2009, page 13). To achieve this purpose, different housing assistance programs are foreseen through a total of nine programs that include the granting of conventional loans, giving subsidies for renting houses, and given special subsidies to rent houses for people in eviction situations and in certain circumstances as being young, elderly or disabled, as well as programs that promote the public park of rental housing, the improvement of energy efficiency and sustainability in housing, conservation, improvement of safety of use and accessibility in housing, and urban and rural regeneration and renewal.

It must be highlighted that all the former programs contained in the Housing Plan 2018-2021 constitute a minimum which can be complemented by the protection and promotion actions foreseen in the legislation of the regional authorities so-called Comunidades Autónomas (Jiménez De Cisneros, 1994, p. 232), with the finality of approving further measures that can improve the State framework about urbanism and housing.

\section{Conclusions}

Housing right protection is not configured as a subjective right, but such as a social right. So, the public authorities must promote and protect it as a value which increases the welfare of the society. The housing policies start when the urbanism planning is approved because is at this moment when public policies could foresee reserves of ground to be lead to social housing, that later on would be offered to citizens who have personal conditions that hinder this access.

Both urban planning and housing plans are the main instruments used to promote the right of access to decent housing. In both recent regulations have some common trends that could be observed: 1 . Promotion of the use of the rural environment, and 2. Promotion of access to housing trough renting, not by purchasing the property.

Effectiveness of housing plans depends on the existence of sheltered housing, and that is originated in the public urbanistic actions, it so could not be denied that it is necessary to contemplate the relationship between 
both. Currently, we observe a point of disconnection between the tools used as public policies of access to decent housing and the limitations for building on rural lands because it cannot be built except when the soil classification changes. Although this limitation is based on the logical function of urbanism that must limit disordered building, the option of allowing small rural constructions, as an accessory of rural soil, when beneficiaries are affected by circumstances that allow them to access to the programs prevented in the housing plans could mean an approach of the urbanistic law and the housing planning currently in force, because it would increase a controlled development in rural spaces and facilitate access to a living space in some cases.

\section{References:}

Agudo González J. (2009), “Gestión urbanística integral del suelo: plusvalías y servicios ambientales”, in Revista de Estudios de la Administración Local y Autonómica REALA $n^{\circ} 311$, pp. 135-167, Ed. Instituto Nacional de Administración Pública, Spain. ISSN 1989-8975.

Alli Aranguren, J. C. (2005), “Urbanismo y vivienda. La interrelación de las políticas de suelo y vivienda", in Revista de Derecho Urbanístico y Medio Ambiente, núm. 219, pp. 59-128, Ed. RDU, Spain. ISSN 1139-4978.

Barrio Andrés M. (2016), "La smart city: versión 2.0 del municipio", in Documentación Administrativa / Nueva época n. ${ }^{\circ}$ 3, pp. 1-6, Ed. Instituto Nacional de Administración Pública, Spain. ISSN 1989-8983.

Bassols Coma M. (2003), "La exclusión social y la contribución de los municipios a la satisfacción del derecho a la vivienda", in Revista de Estudios de la Administración Local REAL no 291, pp. 103-116, Ed. Instituto Nacional de Administración Pública, Spain. ISSN 0034-7639.

Cabello Martínez G. (2011), “El principio de objetividad en el urbanismo”, in Documentación Administrativa / n. ${ }^{\circ} 289$, pp. 233-257, Ed. Instituto Nacional de Administración Pública, Spain. ISSN 1989-8983.

De la Vallina Velarde J.L. (2000), “Panorama actual del Derecho urbanístico”, in Revista de Estudios de la Administración Local y Autonómica REALA nº 283, pp. 329-346, Ed. Instituto Nacional de Administración Pública, Spain. ISSN 1989-8975.

Fernández Méndez M.S. y Justo Rodríguez A. (2017), “A vivenda social como instrumento de políticas redestributivas de renda", in Revista Galega de traballo social $n^{\circ}$ 20, pp.51-82, Ed. Fervenzas, Spain. ISSN 1698-5087. 
García-Bellido García de Diego J. (1998), "La excepcional estructura del urbanismo español en el contexto europeo", in Documentación Administrativa / n. ${ }^{\circ} 252-253$, pp. 12-29, Ed. Instituto Nacional de Administración Pública, Spain. ISSN 1989-8983.

Gardini G. (2018), "Crisis económica y protección de los derechos sociales en Europa. Reflexiones desde el ordenamiento italiano", in REALA. Nueva Época - $N^{o}$ 9, pp. 84-98, Ed. Instituto Nacional de Administración Pública, Spain. ISSN 1989-8975.

González-Varas Ibáñez S. (1992), "La extensión de la obligación municipal de dar alojamiento a sujetos sin vivienda", in Revista de Estudios de la Administración Local REAL $n^{\circ}$ 255-256, pp. 843-846, Ed. Instituto Nacional de Administración Pública, Spain. ISSN 0034-7639.

Iglesias González F. (2005), "La intervención pública en el mercado de la vivienda como política social: problemas actuales y soluciones posibles", in Documentación Administrativa / $n .^{\circ}$ 271-272, pp.516-544, Ed. Instituto Nacional de Administración Pública, Spain. ISSN 1989-8983.

Janer y Durán, E. (1946), “La vivienda económica en las grandes ciudades”, in Revista de Estudios de la Vida Local REVL no 30, pp. 926-937, Ed. Instituto de Estudios de la Administración Local, Spain. ISSN 0034-8163.

Jardí Casany E. (1974), “Congreso de la Federación Internacional de la Vivienda y Urbanismo. Urbanismo y democracia”, in Revista de Estudios de la Vida Local REVL $n^{\circ}$ 181, pp. 73-79, Ed. Instituto de Estudios de la Administración Local, Spain. 0034-8163.

Jiménez De Cisneros (1994), "La cooperación para la formulación y ejecución de planes de vivienda", in Documentación Administrativa / $n .^{\circ}$ 240, pp.229-255, Ed. Instituto Nacional de Administración Pública, Spain. ISSN 1989-8983.

Munar Fullana J. (2000), "El suelo rústico y los criterios de clasificación en la legislación de las Islas Baleares. El mantenimiento del carácter residual en el marco de la Ley 6/1998, sobre Régimen del Suelo y Valoraciones", in Revista de Estudios de la Administración Local y Autonómica REALA no 284, pp. 767-796, Ed. Instituto Nacional de Administración Pública, Spain. ISSN 1989-8975.

Ponce Solé J. (2003), “Inmigración, religión y Derecho urbanístico”, in Quaderns de Dret Local, num. 3, pp.56-71, Ed. Fundación Democracia y Gobierno Local, Spain. ISSN 1696-8438.

Quintana López T. (1999), "El suelo excluido del proceso urbanizador. Referencia a Castilla y León", in Revista de Estudios de la Administración Local REAL $n^{\circ}$ 280-281, pp. 267-289, Ed. Instituto Nacional de Administración Pública, Spain. ISSN 0034-7639. 
Ramón Parada J. (1998-1999), “La privatización del urbanismo español”, in Documentación Administrativa / $n .^{\circ}$ 252-253, pp.105-147, Ed. Instituto Nacional de Administración Pública, Spain. ISSN 1989-8983.

Sánchez Blanco A. (2009), "Urbanismo, prácticas municipales y evaluación institucional del Estado Español: la Resolución del Parlamento Europeo sobre el impacto de la urbanización extensiva en España en los derechos individuales de los ciudadanos europeos, el medio ambiente y la aplicación del Derecho comunitario", in Revista de Estudios de la Administración Local y Autonómica REALA $n^{\circ}$ 310, pp. 9-38, Ed. Instituto Nacional de Administración Pública, Spain. ISSN 1989-8975.

Vaquer Caballería M. (2017), "Planes urbanísticos y planes de vivienda: la extraña pareja”, in REALA. Nueva Época - No 7, pp. 68-85, Ed. Instituto Nacional de Administración Pública, Spain. ISSN 1989-8975. 
